\title{
Pulsed-laser-deposited, single-crystalline Cu2O films with low resistivity achieved through manipulating the oxygen pressure
}

DOI:

10.1016/j.apsusc.2017.11.119

\section{Document Version}

Accepted author manuscript

Link to publication record in Manchester Research Explorer

Citation for published version (APA):

Liu, X., Xu, M., Zhang, X., Wang, W., Feng, X., \& Song, A. (2018). Pulsed-laser-deposited, single-crystalline $\mathrm{Cu}_{2} \mathrm{O}$ films with low resistivity achieved through manipulating the oxygen pressure. Applied Surface Science, 435, 305? 311. https://doi.org/10.1016/j.apsusc.2017.11.119

Published in:

Applied Surface Science

\section{Citing this paper}

Please note that where the full-text provided on Manchester Research Explorer is the Author Accepted Manuscript or Proof version this may differ from the final Published version. If citing, it is advised that you check and use the publisher's definitive version.

\section{General rights}

Copyright and moral rights for the publications made accessible in the Research Explorer are retained by the authors and/or other copyright owners and it is a condition of accessing publications that users recognise and abide by the legal requirements associated with these rights.

\section{Takedown policy}

If you believe that this document breaches copyright please refer to the University of Manchester's Takedown Procedures [http://man.ac.uk/04Y6Bo] or contact uml.scholarlycommunications@manchester.ac.uk providing relevant details, so we can investigate your claim.

\section{OPEN ACCESS}


Surface Science

Elsevier Editorial System(tm) for Applied Manuscript Draft

Manuscript Number: APSUSC-D-17-07664R3

Title: Pulsed-laser-deposited, single-crystalline Cu20 films with low resistivity achieved through manipulating the oxygen pressure

Article Type: Full Length Article

Keywords: copper oxide; PLD; epitaxial; oxygen pressure

Corresponding Author: Professor Xianjin Feng,

Corresponding Author's Institution: Shandong University

First Author: Xiaohui Liu

Order of Authors: Xiaohui Liu; Meng Xu; Xijian Zhang; Weiguang Wang; Xianjin Feng; Aimin Song 
Dear Editor,

We would like to submit the manuscript entitled "Pulsed-laser-deposited, single-crystalline $\mathrm{Cu}_{2} \mathrm{O}$ films with low resistivity achieved through manipulating the oxygen pressure" for possible publication in Applied Surface Science.

$\mathrm{Cu}_{2} \mathrm{O}$ is a well-known p-type semiconductor having promising applications in the electronic and optoelectronic devices such as solar cells and thin film transistors. However, because the film crystal orientation and microstructure as well as the electrical properties could not be well controlled in most of the previously reported $\mathrm{Cu}_{2} \mathrm{O}$ films, the $\mathrm{Cu}_{2} \mathrm{O}$-based functional devices have not shown good performance. In this paper, high quality pulsed-laser-deposited $\mathrm{Cu}_{2} \mathrm{O}$ single crystalline films with low resistivity and high Hall mobility were realized through manipulating the oxygen pressure. The lowest resistivity of $6.67 \Omega \cdot \mathrm{cm}$ and highest mobility of $23.75 \mathrm{~cm}^{2} \cdot \mathrm{v}^{-1} \cdot \mathrm{s}^{-1}$ were obtained for the film prepared at $0.09 \mathrm{~Pa}$, which may have promising applications in solar cells and thin film transistors. This resistivity is also the lowest value reported so far for the pulsed-laser-deposited $\mathrm{Cu}_{2} \mathrm{O}$ films.

This work is original, unpublished, and is not being considered for publication elsewhere. Submission of this work has been checked and approved by all the co-authors.

Thank you for your consideration.

Sincerely yours,

Xianjin Feng 
- High quality singe crystalline $\mathrm{Cu}_{2} \mathrm{O}$ films were deposited on $\mathrm{MgO}$ (110) substrates by PLD.

- The influence of oxygen pressure on the film properties was studied.

- A low resistivity of $6.67 \Omega \cdot \mathrm{cm}$ with a high Hall mobility of $23.75 \mathrm{~cm}^{2} \cdot \mathrm{v}^{-1} \cdot \mathrm{s}^{-1}$ were obtained.

- The optical band gap of the films varied from 2.33 to $2.57 \mathrm{eV}$. 
Dear Editor and Reviewer:

Thank you very much for giving us the opportunity to revise our manuscript entitled 'Pulsed-laser-deposited, single-crystalline $\mathrm{Cu}_{2} \mathrm{O}$ films with low resistivity achieved through manipulating the oxygen pressure" (Ms. Ref. No.: APSUSC-D-17-07664R2). The comments and suggestions are all valuable and helpful for revising and improving our paper. We have studied the comments carefully and have made corrections which we hope will meet with approval. Our responses to the Reviewer's comments are as follows:

Reviewer \#1 Comment: In response to my first comments the Authors have satisfied the majority of my queries. However, one important, fundamental scientific point is still needed to be addressed:

It is impossible to say that $\mathrm{Cu}_{2} \mathrm{O}[111] / / \mathrm{MgO}$ [111]. Even small strains of $1.4 \%$ will effect a distortion in-plane and, thus through Poisson's ratio also out-of-plane, in the film material. This is clear. The $\{111\}$ directions in the film and substrate will be close to but not exactly parallel because of this distortion. In the response to comment 1 in the first review the authors write "As can be seen in Fig. 2, the peak positions of $\mathrm{Cu}_{2} \mathrm{O}\{111\}$ and $\mathrm{MgO}\{111\}$ planes coincide very well, indicating an epitaxial relationship of $\mathrm{Cu}_{2} \mathrm{O}[111] / / \mathrm{MgO}[111] "$. This is completely incorrect and indicates that they do not understand the measurement. The phi scan in Figure 2 is a standard method to assess epitaxy. Here the diffractometer is aligned to a reflection that has an off-axis (in this case the [111]) of both the film and substrate, a rotation about the normal of the sample is then initiated. Seeing reflections for both film and substrate in the same positions shows that the crystal lattices for both materials are aligned in-plane. In this case, this means that $\mathrm{Cu}_{2} \mathrm{O}(100) / / \mathrm{MgO}(100)$ and $\mathrm{Cu}_{2} \mathrm{O}(011) / / \mathrm{MgO}(011)$. However, as only one axis of the diffractometer is actioned, it is 
impossible to distinguish if the out of plane component is well aligned, in fact it is probably not due to substrate imposed strain. The only way to test if the $\mathrm{Cu}_{2} \mathrm{O}[111] / / \mathrm{MgO}[111]$ is to do a reciprocal space map around the (111) reflection. If there is only a single peak, then one can say that $\mathrm{Cu}_{2} \mathrm{O}[111] / / \mathrm{MgO}$ [111]. Here, it would be typical to see a doublet due to substrate strain.

Our comment and action: We are sorry for our inadequate understanding of phi scan and inappropriate description of the epitaxial relationship. The inappropriate description has been corrected and the relevant text has been revised. (See the Abstract \& paragraph 1, page 8 \& paragraph 1, page $10 \&$ paragraph 2, page 16)

Thanks a lot again for your kind help and such important comments. We tried our best to improve the manuscript and made some changes in the manuscript which were marked in red in the revised paper. Now we send the revised manuscript back to you, and hope it is OK now. Thank you for your reconsideration.

Yours sincerely,

Xianjin Feng 


\title{
Pulsed-laser-deposited, single-crystalline $\mathrm{Cu}_{2} \mathrm{O}$ films with low resistivity achieved through manipulating the oxygen pressure
}

Xiaohui Liu ${ }^{\mathrm{a}}$, Meng Xu ${ }^{\mathrm{a}}$, Xijian Zhang ${ }^{\mathrm{a}}$, Weiguang Wang ${ }^{\mathrm{a}}$, Xianjin Feng ${ }^{\mathrm{a}, *}$, Aimin Song ${ }^{\mathrm{a}, \mathrm{b}}$

${ }^{\mathrm{a} C e n t e r}$ of Nanoelectronics and School of Microelectronics, Shandong University, Jinan 250100, China

${ }^{\mathrm{b}}$ School of Electrical and Electronic Engineering, University of Manchester, Manchester M13 9PL, United Kingdom

\begin{abstract}
Low-resistivity, single-crystalline $\mathrm{Cu}_{2} \mathrm{O}$ films were realized on $\mathrm{MgO}$ (110) substrates through manipulating the oxygen pressure $\left(\mathrm{P}_{\mathrm{O}_{2}}\right)$ of pulsed-laser deposition. X-ray diffraction and high resolution transmission electron microscopy measurements revealed that the films deposited at $\mathrm{P}_{\mathrm{O}_{2}}$ of 0.06 and $0.09 \mathrm{~Pa}$ were single phase $\mathrm{Cu}_{2} \mathrm{O}$ and the 0.09-Pa-deposited film exhibited the best crystallinity with an epitaxial relationship of $\mathrm{Cu}_{2} \mathrm{O}(110) / / \mathrm{MgO}$ (110) with $\mathrm{Cu}_{2} \mathrm{O}(001) / / \mathrm{MgO}$ (001). The pure phase $\mathrm{Cu}_{2} \mathrm{O}$ films exhibited higher transmittances and larger band gaps with an optical band gap of $2.56 \mathrm{eV}$ obtained for the 0.09 Pa-deposited film. Hall-effect measurements demonstrated that the $\mathrm{Cu}_{2} \mathrm{O}$ film deposited at $0.09 \mathrm{~Pa}$ had the lowest resistivity of $6.67 \Omega \cdot \mathrm{cm}$ and highest Hall mobility of $23.75 \mathrm{~cm}^{2} \cdot \mathrm{v}^{-1} \cdot \mathrm{s}^{-1}$.
\end{abstract}

Keyword: copper oxide; PLD; epitaxial; oxygen pressure

*Corresponding author: Tel.: +86 531 88363606; fax: +86 53188564886.

E-mail addresses: xianjinfeng@sdu.edu.cn (X. Feng). 


\section{Introduction}

Depending on the crystal bonding and structure between the metal cation and oxygen, metal oxides show quite different functional properties. Metal oxides could exhibit magnetic, insulating, conducting and semiconducting properties [1]. Metal oxide semiconductors were applied to fabrication of various devices such as light emitting devices, thin film transistors (TFTs) and solar cells [2]. Cuprous oxide $\left(\mathrm{Cu}_{2} \mathrm{O}\right)$ is a well-known p-type semiconductor. It has a direct band gap $\left(\mathrm{E}_{\mathrm{g}}=2.0-2.6 \mathrm{eV}\right)$ [3-7] and can exhibit a hole mobility exceeding $100 \mathrm{~cm}^{2} \cdot \mathrm{v}^{-1} \cdot \mathrm{s}^{-1}$ at room temperature [8]. $\mathrm{Cu}_{2} \mathrm{O}$ is also regarded as one of the promising functional materials for its abundance, nontoxicity and large optical absorption coefficient [9]. There are many reports on $\mathrm{Cu}_{2} \mathrm{O}$-based solar cells and thin film transistors [10-14]. However, the highest reported energy conversion efficiency of $\mathrm{Cu}_{2} \mathrm{O}$ solar cells was only around $6.1 \%$ with the $\mathrm{Cu}_{2} \mathrm{O}$ active layer formed through oxidation of $\mathrm{Cu}$ sheets [12] even though the maximum theoretical conversion efficiency is $20 \%$ [15]. For $\mathrm{Cu}_{2} \mathrm{O}$ thin film transistors, the performance is also unsatisfactory. Yao et al. demonstrated a p-type TFT formed by sputtered $\mathrm{Cu}_{2} \mathrm{O}$, showing a field effect mobility of $\sim 2.40$ $\mathrm{cm}^{2} \cdot \mathrm{v}^{-1} \cdot \mathrm{s}^{-1}$ and an on/off current ratio of $\sim 3.96 \times 10^{4}[13]$. Using the atomic layer deposition method, Maeng's group fabricated a p-type $\mathrm{Cu}_{\mathrm{x}} \mathrm{O}$ TFT with a field effect mobility of $5.64 \mathrm{~cm}^{2} \cdot \mathrm{v}^{-1} \cdot \mathrm{s}^{-1}$, an on/off current ratio of $1.79 \times 10^{5}$, and a subthreshold swing of $0.75 \mathrm{~V} / \mathrm{decade}[14]$. Because the film crystal orientation and microstructure as well as the electrical properties could not be well controlled in most of the 
previously reported $\mathrm{Cu}_{2} \mathrm{O}$ films, $\mathrm{Cu}_{2} \mathrm{O}$-based functional devices have not shown good performance. It is therefore necessary to obtain high quality $\mathrm{Cu}_{2} \mathrm{O}$ films with good electrical properties (high Hall mobility, proper resistivity)in order to further improve the performance of $\mathrm{Cu}_{2} \mathrm{O}$-based functional devices [16].

During the past years, in order to obtain high quality $\mathrm{Cu}_{2} \mathrm{O}$ films, many methods such as sputtering [5], thermal oxidation [10], evaporation [17], molecular beam epitaxy [18], and electrodeposition [19] have been used. Due to the high kinetic energy of the ionized and ejected species in the laser produced plasma, pulsed-laser deposition (PLD) technique could deposit highly oriented crystalline films at low substrate temperatures $[20,21]$. Furthermore, PLD is very suited to stoichiometric growth due to its operating far away from equilibrium [22]. However, until now, there are only a few reports on $\mathrm{Cu}_{2} \mathrm{O}$ films prepared by PLD and the influence of oxygen pressure $\left(\mathrm{P}_{\mathrm{O}_{2}}\right)$ during the deposition on the film properties was especially rarely studied $[23,24]$. Moreover, the reported pulsed-laser deposited $\mathrm{Cu}_{2} \mathrm{O}$ films usually had high electrical resistivities in the range of $10^{2}-10^{5} \Omega \cdot \mathrm{cm}$ [24-26], which are not suitable to be used in both solar cells and thin film transistors. It is well-known that the optimum resistivity for the absorber layer in a solar cell is around $0.1-1 \Omega \cdot \mathrm{cm}$ [27]. While for high performance thin film transistors, the typical carrier concentration of the channel layer is usually in the range of $10^{16}-10^{17} \mathrm{~cm}^{-3}[28,29]$ with a Hall mobility higher than $10 \mathrm{~cm}^{2} \cdot \mathrm{v}^{-1} \cdot \mathrm{s}^{-1}$ (normally the higher the better), leading to a resistivity value lower than $10^{2} \Omega \cdot \mathrm{cm}$.

In this work, copper oxide films were prepared on $\mathrm{MgO}$ (110) substrates by PLD 
and the structural, optical and electrical properties of the films as a function of $\mathrm{P}_{\mathrm{O}_{2}}$ were investigated in detail. $\mathrm{MgO}$ (110) was chosen as substrate because the lattice mismatch between $\mathrm{MgO}$ and $\mathrm{Cu}_{2} \mathrm{O}$ is very small ( 1.4\%), and the $\mathrm{Cu}_{2} \mathrm{O}$ (110) plane has relatively lower surface free energies than other planes making it easier to be epitaxially grown [30]. High quality single-crystalline $\mathrm{Cu}_{2} \mathrm{O}$ film with a low electrical resistivity of $6.67 \Omega \cdot \mathrm{cm}$ and a high Hall mobility of $23.75 \mathrm{~cm}^{2} \cdot \mathrm{v}^{-1} \cdot \mathrm{s}^{-1}$ was obtained through manipulating the oxygen pressure, which may have promising applications in solar cells and thin film transistors.

\section{Experimental}

High vacuum PLD system with a KrF excimer laser (wavelength: $248 \mathrm{~nm}$, pulse duration: $20 \mathrm{~ns}$, pulse frequency: $20 \mathrm{~Hz}$ ) and a ceramic $\mathrm{Cu}_{2} \mathrm{O}$ target (4N purity) was used to deposit the copper oxide thin films. $\mathrm{MgO}$ (110) single crystals substrates were mounted $8 \mathrm{~cm}$ away from target in the PLD chamber with a base pressure under $10^{-4}$ $\mathrm{Pa}$. The laser energy density was $\sim 6 \mathrm{~J} / \mathrm{cm}^{2}$ at the target surface. Growth condition was varied in the range of $\mathrm{P}_{\mathrm{O}_{2}}=0.02-0.12 \mathrm{~Pa}$ at a fixed substrate temperature of $600^{\circ} \mathrm{C}$, where $\mathrm{Cu}_{2} \mathrm{O}$ is the stable phase in a phase equilibrium diagram [31].

The out-of-plane $\theta-2 \theta$ and in-plane $\Phi$ and $2 \theta \chi$-scans were measured using respectively the Rigaku and Philips X'Pert PRO X-ray diffractometers (XRD) to determine the crystalline quality and epitaxial relationship. A FEI Nova NanoSEM 450 field emission scanning electron microscope (SEM) was used to observe the surface morphology. The atomic arrangements across the substrate-film interface were 
observed using high resolution transmission electron microscopy (HRTEM) and selected-area electron diffraction (SAED) with a Tecnai F30 transmission electron microscope operated at $300 \mathrm{kV}$. The chemical composition was measured by the X-ray photoelectron spectroscopy (XPS) using an ESCALAB MK II multi-technique electron spectrometer. A TU-1901 double-beam UV-vis-NIR spectrophotometer was used to measure the optical transmittance. The electrical properties were measured by Van der Pauw method.

\section{Results and discussion}

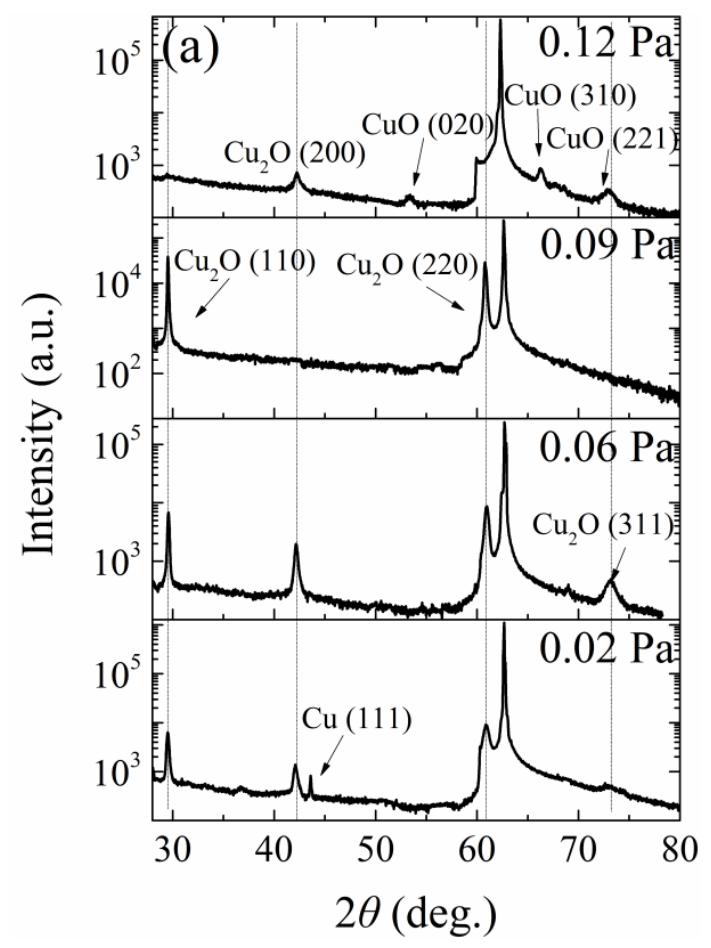




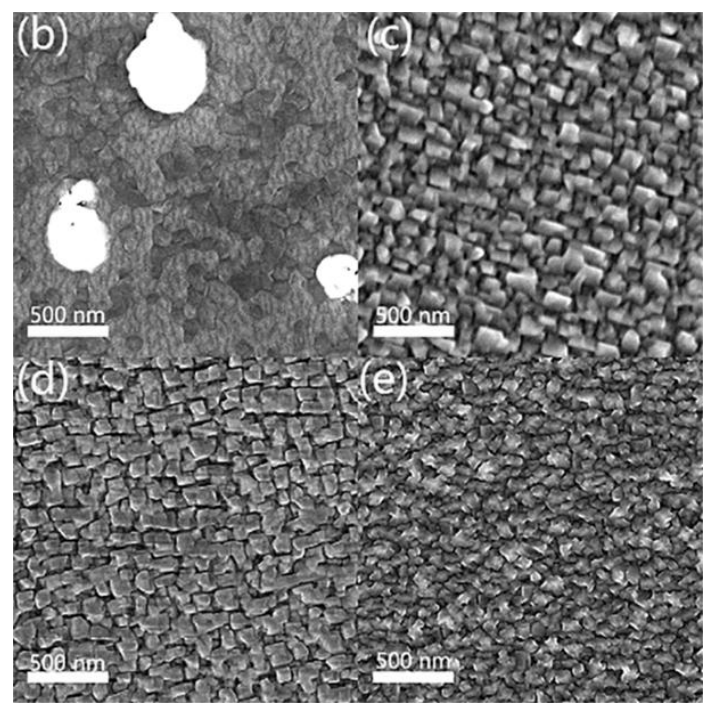

Fig. 1. (a) XRD patterns of copper oxide films grown on $\mathrm{MgO}$ (110) substrates under typical oxygen pressures. Plan view SEM micrographs of the copper oxide films grown under the oxygen pressures of (b) 0.02, (c) 0.06, (d) 0.09 and (e) $0.12 \mathrm{~Pa}$.

The crystallinity of the as-grown copper oxide films was investigated by XRD. Fig. 1(a) shows typical patterns of $\theta-2 \theta$ scan for the copper oxide films deposited under representative oxygen pressures. Besides the substrate diffraction peak of $\mathrm{MgO}$ (220) located at $62.4^{\circ}$ (JCPDS No.65-0476), five other peaks located respectively at $29.5^{\circ}, 42.1^{\circ}, 43.6^{\circ}, 60.8^{\circ}$ and $73.5^{\circ}$ can be seen at $0.02 \mathrm{~Pa}$, which are identified as $\mathrm{Cu}_{2} \mathrm{O}$ (110), $\mathrm{Cu}_{2} \mathrm{O}$ (200), $\mathrm{Cu}$ (111), $\mathrm{Cu}_{2} \mathrm{O}$ (220) and $\mathrm{Cu}_{2} \mathrm{O}$ (311) (JCPDS No.65-3288 for $\mathrm{Cu}_{2} \mathrm{O}$, No.04-0836 for $\mathrm{Cu}$ ), indicating the presence of a mixed phase of $\mathrm{Cu}_{2} \mathrm{O}$ and $\mathrm{Cu}$. With the increase of $\mathrm{P}_{\mathrm{O}_{2}}$ to $0.06 \mathrm{~Pa}$, the $\mathrm{Cu}$ (111) peak disappears, indicating the existence of single phase $\mathrm{Cu}_{2} \mathrm{O}$. For the sample fabricated under $\mathrm{P}_{\mathrm{O}_{2}}$ of $0.09 \mathrm{~Pa}$, only the $\mathrm{Cu}_{2} \mathrm{O}$ (110) and (220) peaks can be observed in addition to the substrate peak, indicating that a single orientation along the $\mathrm{Cu}_{2} \mathrm{O}$ (110) direction is obtained. With 
the further increase of $\mathrm{P}_{\mathrm{O}_{2}}$ to $0.12 \mathrm{~Pa}$, the $\mathrm{CuO}$ (020) and (310) peaks (JCPDS No.48-1548) as well as the $\mathrm{Cu}_{2} \mathrm{O}$ (200) peaks are visible, indicating a mixed phase of $\mathrm{Cu}_{2} \mathrm{O}$ and $\mathrm{CuO}$ and the degradation of film crystalline quality. It should be noticed that, due to the close $2 \theta$ values of $\mathrm{CuO}$ (221) and $\mathrm{Cu}_{2} \mathrm{O}$ (311) reflections, the peak at around $73.5^{\circ}$ is hard to distinguish for the $0.12 \mathrm{~Pa}$-deposited sample and therefore it may be considered as a combined peak of these two reflections. While for the 0.02 and $0.06 \mathrm{~Pa}$-deposited samples, considering the pure $\mathrm{Cu}_{2} \mathrm{O}$ phase of the film grown at $0.09 \mathrm{~Pa}$, it is reasonable to assign this peak to $\mathrm{Cu}_{2} \mathrm{O}$ (311) rather than $\mathrm{CuO}$ (221) for the films prepared at such lower oxygen pressures.

It is well-known that the $\mathrm{Cu}-\mathrm{O}$ phase is strongly influence by the thermodynamic conditions (substrate temperature and oxygen pressure). However, for the non-equilibrium physical vapor deposition process PLD, the increase of total chamber pressure i.e. the oxygen pressure in our study can also alter the plasma dynamics by changing the target-to-substrate transport from the ballistic to the diffuse regime, which in turn can result in the formation of different $\mathrm{Cu}-\mathrm{O}$ phases [32]. Therefore, the $\mathrm{Cu}-\mathrm{O}$ phase transition in our study could be attributed to the combination of pressure related kinetic and thermodynamic effects. The results of XRD measurement reveal that the film structure and crystallinity are strongly influenced by oxygen pressure and the $0.09 \mathrm{~Pa}$-deposited film has the best crystalline quality.

Fig. 1(b), (c), (d) and (e) show the plan view SEM images of copper oxide films deposited under $\mathrm{P}_{\mathrm{O}_{2}}$ of $0.02,0.06,0.09$ and $0.12 \mathrm{~Pa}$, respectively. In Fig. 1(b), submicron particles can be observed on the surface of the $0.02 \mathrm{~Pa}$-deposited film, for 
which metallic $\mathrm{Cu}$ that mainly exists at the surface of the particles is assumed to act as a catalyst of their growth [32]. Fig. 1(c) exhibits irregular grains and disordered grain edges due to the polycrystalline structure of this sample. In Fig. 1(d), a compact surface with regularly-shaped islands and well-defined boundaries could be observed, which corresponds to the best crystallization of the sample prepared at $0.09 \mathrm{~Pa}$. A surface with ill-defined grain formation is observed for the film deposited under 0.12 $\mathrm{Pa}$ as shown in Fig. 1(e), due to the mixed phase of this sample as revealed by the XRD analyses. As mentioned above, the plasma dynamics and therefore the growth mode of the films in our study can be influenced by the different oxygen pressures. The variation of growth mode together with the $\mathrm{Cu}-\mathrm{O}$ phase transition will result in the different observed film surface morphologies. The SEM analyses illustrate obviously that the oxygen pressure has a strong influence on the film morphology and crystallinity, which are consistent with the $\mathrm{XRD}$ results.

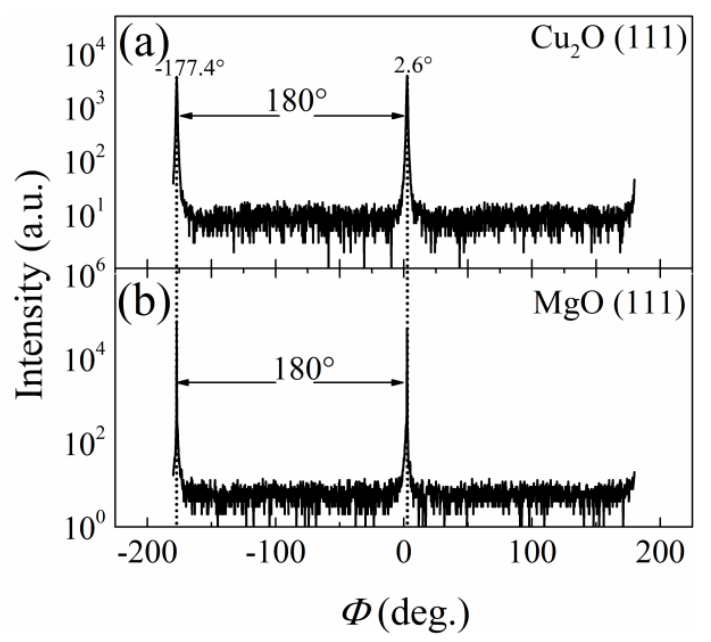




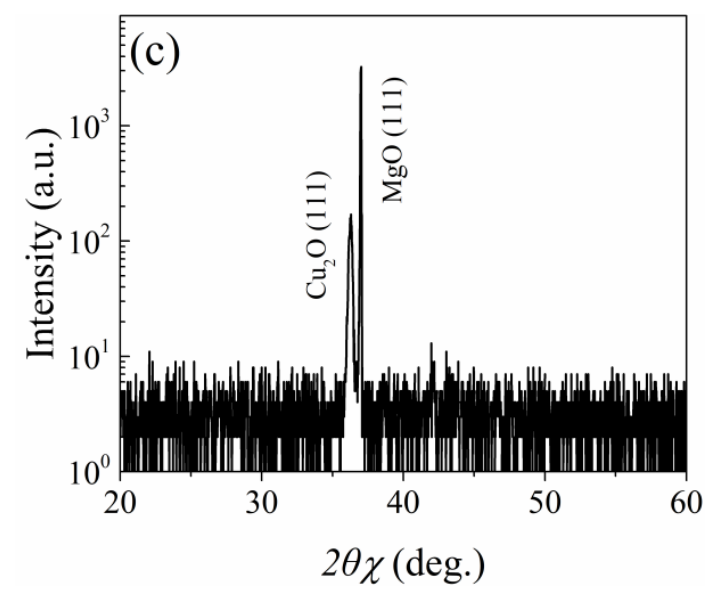

Fig. 2. In-plane XRD patterns of (a) and (b) $\Phi$-scan as well as (c) $2 \theta \chi$-scan for the sample grown under $\mathrm{P}_{\mathrm{O}_{2}}$ of $0.09 \mathrm{~Pa}$.

The off-specular $\Phi$-scan of $\mathrm{Cu}_{2} \mathrm{O}\{111\}$ planes $\left(\Psi=35.26^{\circ}\right)$ for the 0.09 Pa-deposited film is shown in Fig. 2(a). Two diffraction peaks separated by $180^{\circ}$ of the $\mathrm{Cu}_{2} \mathrm{O}\{111\}$ planes indicate a good in-plane alignment inside the film. The $\{111\}$ plane of $\mathrm{Cu}_{2} \mathrm{O}$ is two-fold symmetrical along $\mathrm{Cu}_{2} \mathrm{O}$ [110], which is consistent with Fig. 2(a), indicating a complete single-crystalline structure without any domains in the obtained film. Fig. 2(b) shows the off-specular $\Phi$-scan of $\mathrm{MgO}\{111\}$ planes $\left(\Psi=35.26^{\circ}\right)$ for the substrate, from which two diffraction peaks separated by $180^{\circ}$ with the same $\Phi$-angles as the $\mathrm{Cu}_{2} \mathrm{O}\{111\}$ planes could be seen, indicating that the crystal lattices for both materials are aligned in-plane with an epitaxial relationship of $\mathrm{Cu}_{2} \mathrm{O}$ (110) // $\mathrm{MgO}(110)$ and $\mathrm{Cu}_{2} \mathrm{O}(001) / / \mathrm{MgO}(001)$. To further confirm that the peaks in Fig. 2(a) are really from the film and not the tail end of the substrate peaks, we have performed the in-plane $2 \theta \chi$-scan of the sample at the fixed $\Phi$ and $\Psi$ angles, as shown in Fig. 2(c). Only two distinct peaks of $\mathrm{Cu}_{2} \mathrm{O}$ (111) and $\mathrm{MgO}$ (111) can be seen 
obviously, confirming the (111) reflections from the substrate and film are distinguishable. These results reveal that the $\mathrm{Cu}_{2} \mathrm{O}$ film deposited under the $\mathrm{P}_{\mathrm{O}_{2}}$ of $0.09 \mathrm{~Pa}$ is epitaxial single crystal with no twins and the epitaxial relationship is $\mathrm{Cu}_{2} \mathrm{O}$ (110) // $\mathrm{MgO}(110)$ with $\mathrm{Cu}_{2} \mathrm{O}(001) / / \mathrm{MgO}(001)$.
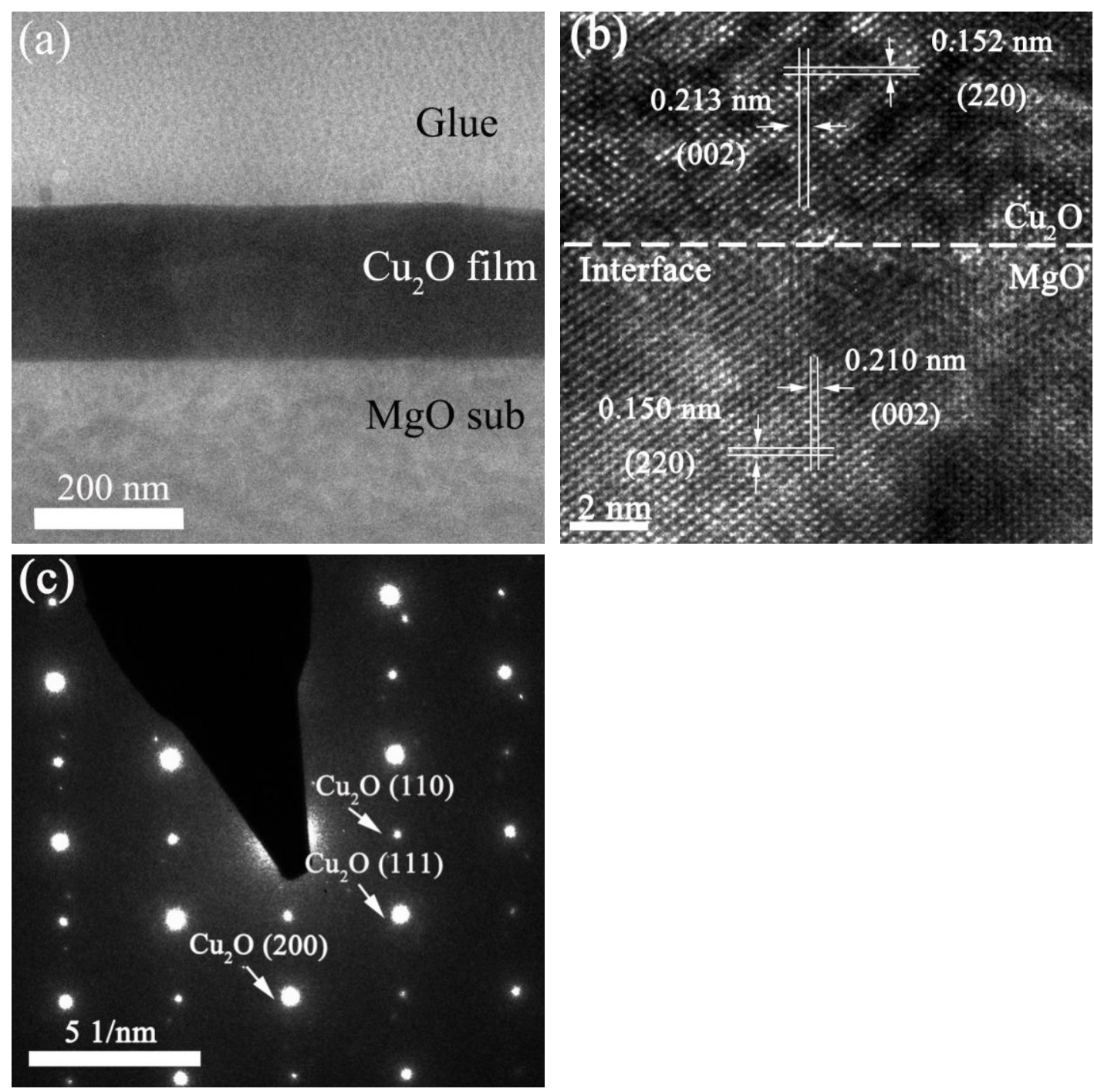

Fig. 3. (a) Low magnification TEM and (b) HRTEM images of the film-substrate interface and (c) SAED micrographs of the film portion for the 0.09 Pa-deposited sample. 
The cross-sectional TEM measurements were performed to further study the atomic arrangements and microstructure of the sample deposited under $\mathrm{P}_{\mathrm{O}_{2}}$ of $0.09 \mathrm{~Pa}$. From the low magnification TEM image as shown in Fig. 3(a), a compact film without any columnar structures inside as well as a clean and sharp interface between the film and the substrate are observed. The HRTEM image of the interface between the $\mathrm{Cu}_{2} \mathrm{O}$ film and $\mathrm{MgO}$ substrate and the SAED pattern of the $\mathrm{Cu}_{2} \mathrm{O}$ film are shown respectively in Fig. 3(b) and (c). The incident electron beam was parallel to the [ $\overline{1} 10]$ direction of the $\mathrm{MgO}$ substrate. Uniform and ordered crystal lattice arrays of both the $\mathrm{Cu}_{2} \mathrm{O}$ film and $\mathrm{MgO}$ substrate can be seen clearly in Fig. 3(b). The spacings of the as-marked lattice planes in the $\mathrm{Cu}_{2} \mathrm{O}$ film area are about $0.152 \mathrm{~nm}$ and $0.213 \mathrm{~nm}$, corresponding respectively to the $\mathrm{Cu}_{2} \mathrm{O}$ (220) and (002) planes with a standard angular separation of $90^{\circ}$ inbetween. For the $\mathrm{MgO}$ substrate, the as-marked interplane spacings are 0.150 and $0.210 \mathrm{~nm}$, which are consistent respectively with the $\mathrm{MgO}$ (220) and (002) planes. In the SAED pattern of the $\mathrm{Cu}_{2} \mathrm{O}$ film shown in Fig. 3(c), the $\mathrm{Cu}_{2} \mathrm{O}$ (110), (200) and (111) diffraction spots are clearly observed. The distinct and regular diffraction spot array implies good single crystallinity of this film. From the HRTEM analyses, the epitaxial relationship between $\mathrm{Cu}_{2} \mathrm{O}$ film and $\mathrm{MgO}$ substrate can be obtained as $\mathrm{Cu}_{2} \mathrm{O}(110) / / \mathrm{MgO}$ (110) with $\mathrm{Cu}_{2} \mathrm{O}(001) / / \mathrm{MgO}(001)$, which is consistent with the XRD analyses, indicating the single crystalline structure of this film. 

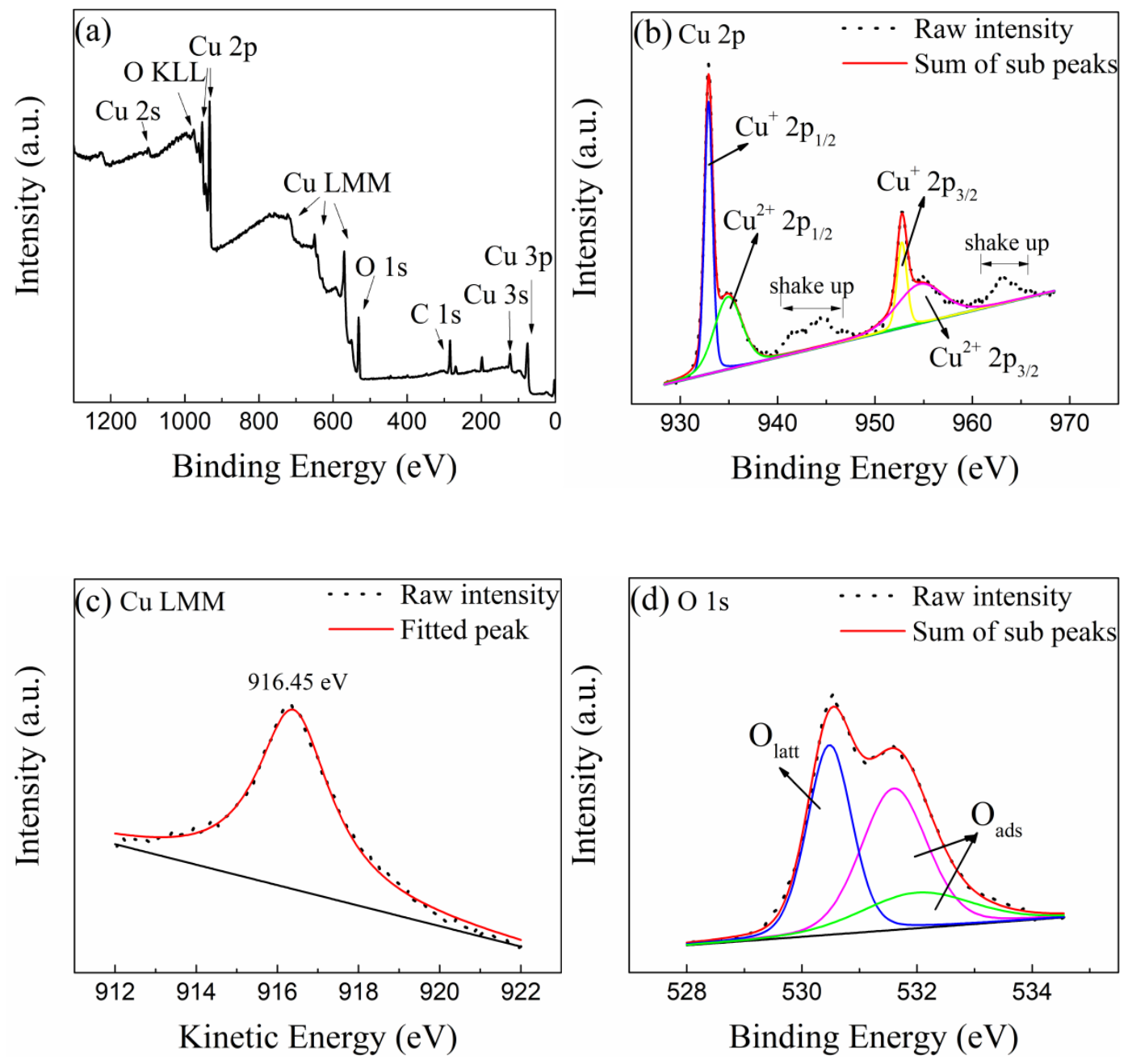

Fig. 4. XPS spectra of the $\mathrm{Cu}_{2} \mathrm{O}$ film grown under $\mathrm{P}_{\mathrm{O}_{2}}$ of $0.09 \mathrm{~Pa}$ : (a) survey, (b) $\mathrm{Cu} 2 \mathrm{p}$ core levels,

(c) $\mathrm{Cu}$ LMM Auger spectrum and (d) O 1s core level.

The chemical states of different elements of the $\mathrm{Cu}_{2} \mathrm{O}$ film prepared at $\mathrm{P}_{\mathrm{O}_{2}}$ of 0.09 Pa were investigated by XPS. As shown in Fig. 4(a), photoelectron peaks of O 1s, O KLL Auger, $\mathrm{Cu}$ LMM Auger, $\mathrm{Cu} 2 \mathrm{p}, \mathrm{Cu} 2 \mathrm{~s}, \mathrm{Cu} 3 \mathrm{p}, \mathrm{Cu} 3 \mathrm{~s}$ and $\mathrm{C} 1 \mathrm{~s}$ can be observed in the survey spectrum. The $\mathrm{C} 1 \mathrm{~s}$ peak is due to the adventitious hydrocarbon contamination on the film surface. The XPS spectra of $\mathrm{Cu} 2 \mathrm{p}$ and $\mathrm{O} 1$ s core levels were numerically fitted with four and three Lorentzian-Gaussian (Lorentzian: 20\%) features, corresponding to Fig.4 (b) and (d), respectively. The fitted $\mathrm{Cu} 2 \mathrm{p}$ core levels 
displayed in Fig. 4(b), which show two main peaks at 932.8 and $952.8 \mathrm{eV}$ corresponding respectively to the $2 \mathrm{p}_{3 / 2}$ and $2 \mathrm{p}_{1 / 2}$ levels of $\mathrm{Cu}^{1+}$ state $\left(\mathrm{Cu}_{2} \mathrm{O}\right)$ [16]. The shoulder peaks at 935.1 and $955.2 \mathrm{eV}$ together with the shake-up satellite peaks in the 940-945 and 960-965 eV regions can also be observed, indicating the presence of $\mathrm{Cu}^{2+}$ state $(\mathrm{CuO})$ on the film surface [33], which is normally formed by exposure in humid air after the deposition of $\mathrm{Cu}_{2} \mathrm{O}$. Since the main peaks of $\mathrm{Cu} 2 \mathrm{p}$ at the same positions can also be assigned to metallic $\mathrm{Cu}$, the $\mathrm{Cu}$ LMM Auger transition was investigated as well. As can be seen from Fig. 4(c), the Cu LMM Auger spectrum with Lorentzian peak fit has only one feature with a kinetic energy of $916.45 \mathrm{eV}$. It has been reported that the $\mathrm{Cu}^{0}$ (metallic $\mathrm{Cu}$ ) Auger spectrum has a distinct satellite feature at kinetic energy of $\sim 2.5 \mathrm{eV}$ higher than the main peak [16], the absence of which rules out the existence of metallic $\mathrm{Cu}$. The fitted $\mathrm{O}$ 1s spectrum shown in Fig. 4(d) has three distinct peak contributions. The peak at lower binding energy (around $530.5 \mathrm{eV}$ ) denoted as $\mathrm{O}_{\text {latt }}$ represents the lattice oxygen of $\mathrm{Cu}_{2} \mathrm{O}$ and/or $\mathrm{CuO}$ and the peaks at higher binding energy $(531.6-532.0 \mathrm{eV})$ denoted as $\mathrm{O}_{\text {ads }}$ belongs most likely to the adsorbed oxygen and/or hydroxyl group [34]. 

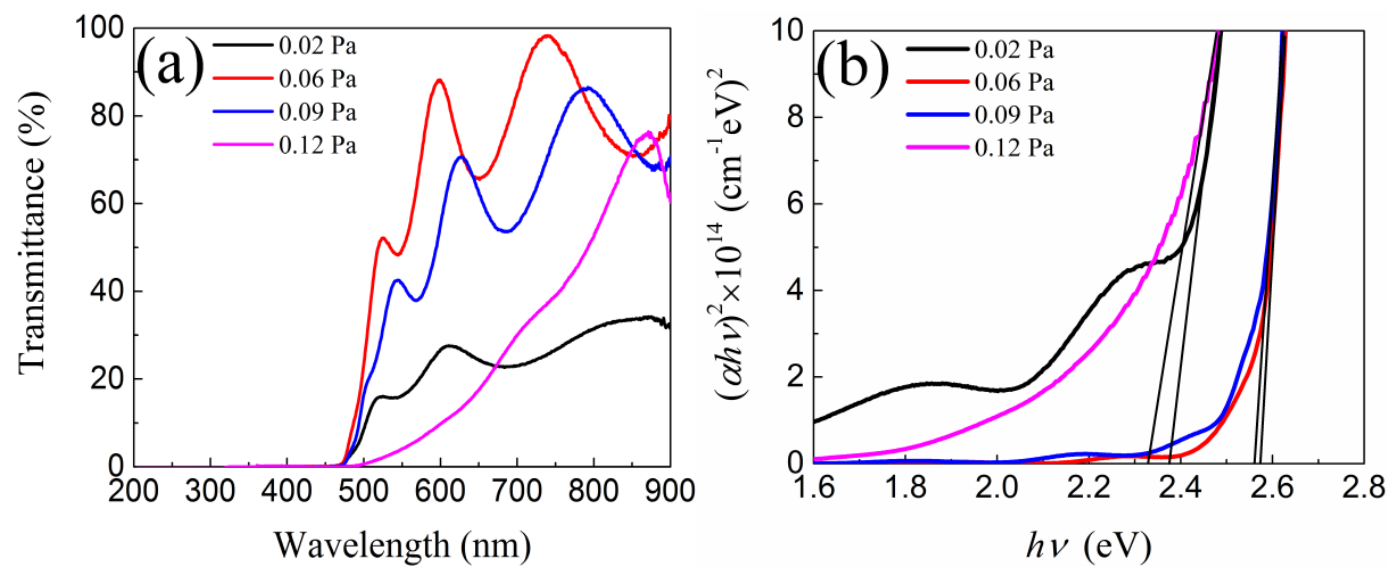

Fig. 5. Transmittance spectra of the copper oxide films prepared under typical oxygen pressures with the plots of $(\alpha h v)^{2}$ versus $h v$ shown in the inset.

The transmittance spectra of copper oxide films prepared under typical oxygen pressures are displayed in Fig. 5(a). It can be seen that under the $\mathrm{P}_{\mathrm{O}_{2}}$ of $0.02 \mathrm{~Pa}$, as a result of the existence of opaque metallic copper phase, the film presents feeble transmittance. For the samples deposited under 0.06 and $0.09 \mathrm{~Pa}$, on the one hand, the films are pure phase $\mathrm{Cu}_{2} \mathrm{O}$ with large band gap, without any narrow-band-gap materials that can absorb long wavelength light existent. On the other hand, the $\mathrm{Cu}_{2} \mathrm{O}$ film crystallinity is improved with fewer structural defects present, which will subsequently decrease the light scattering and the defect level related light absorption. Both factors mentioned above may lead to the high transmittance of these two films. As the $\mathrm{P}_{\mathrm{O}_{2}}$ increases further to $0.12 \mathrm{~Pa}$, resulting from the presence of $\mathrm{CuO}\left(\mathrm{E}_{\mathrm{g}}=\right.$ 1.2-2.0 eV) [35] and degraded crystallinity, the transmittance of film decreases obviously. In addition, much sharper absorption edges are observed for the pure $\mathrm{Cu}_{2} \mathrm{O}$ films than the films having impurity phases. Fig. 5(b) shows the Tauc plots of the 
copper oxide films. The band gaps of copper oxide films are estimated with Tauc's equation for direct transition gaps in semiconductors given by [36]

$$
(\alpha h v)^{2}=A\left(h v-E_{g}\right)
$$

where $\alpha$ is the absorption coefficient, $\mathrm{A}$ is a material dependent constant, $\mathrm{h}$ is the Planck constant, $v$ is the frequency and $E_{g}$ is the optical energy band gap. The absorption coefficient $\alpha$ can be calculated from the thickness (d) and transmittance(T) of the film by using the well-known equation of [37]

$\alpha=\frac{1}{d} \ln \left(\frac{1}{T}\right)$.

Therefore, the $\mathrm{E}_{\mathrm{g}}$ values can be derived through plotting $(\alpha h v)^{2} \mathrm{vs} . h v$ followed by extrapolating the straight-line portion of this plot to the energy axis as exhibited in the Fig. 5(b). The $\mathrm{E}_{\mathrm{g}}$ values of 2.37, 2.57, 2.56 and $2.33 \mathrm{eV}$ are obtained for the films deposited under oxygen pressures of $0.02,0.06,0.09$ and $0.12 \mathrm{~Pa}$, respectively. The $\mathrm{E}_{\mathrm{g}}$ values and variation tendency in our study are similar to the results of previously reported works [7, 38].

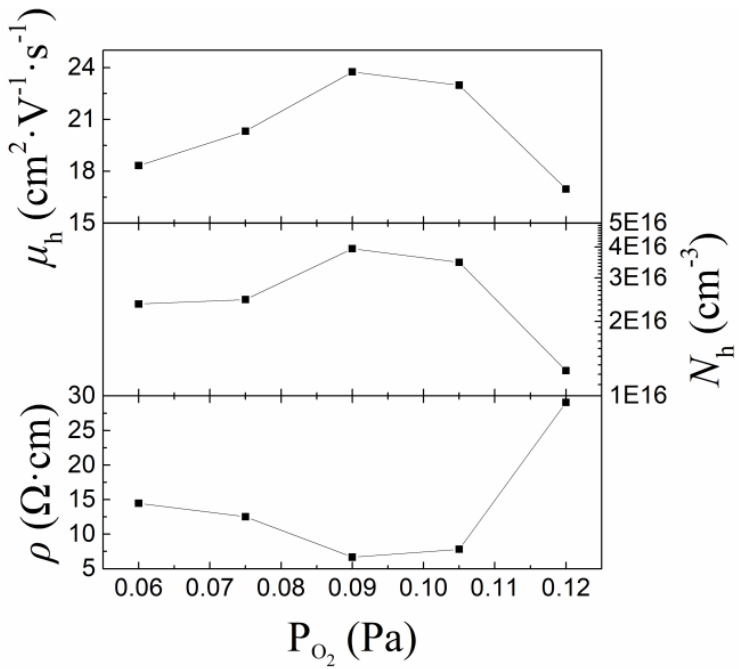


Fig. 6. Hall mobility, carrier concentration and resistivity of the copper oxide films as a function of the oxygen pressure.

Fig. 6 shows the dependence of Hall mobility, carrier concentration and electrical resistivity on the oxygen pressure for the copper oxide thin films. The p-type conductivity was confirmed for all the samples shown in Fig.6 during the measurement. The film deposited at $0.02 \mathrm{~Pa}$ possesses insulating property probably due to the existence of metallic $\mathrm{Cu}$ and the consequent compensation of holes. With the increase of $\mathrm{P}_{\mathrm{O}_{2}}$ to $0.06 \mathrm{~Pa}$, the deposited film becomes single phase $\mathrm{Cu}_{2} \mathrm{O}$ and the resistivity decreases. As the $\mathrm{P}_{\mathrm{O}_{2}}$ increases further to $0.09 \mathrm{~Pa}$, both of the Hall mobility and carrier concentration increase mainly due to the improvement of crystallinity and increased number of $\mathrm{Cu}$ vacancies, respectively, resulting in the decrease of resistivity. The $\mathrm{Cu}_{2} \mathrm{O}$ film deposited under $\mathrm{P}_{\mathrm{O}_{2}}$ of $0.09 \mathrm{~Pa}$ possesses the lowest electrical resistivity of $6.67 \Omega \cdot \mathrm{cm}$ with the highest carrier concentration of $3.94 \times 10^{16} \mathrm{~cm}^{-3}$ and highest mobility of $23.75 \mathrm{~cm}^{2} \cdot \mathrm{v}^{-1} \cdot \mathrm{s}^{-1}$ among all the copper oxide thin films deposited in this work. To the best our knowledge, the resistivity of $6.67 \Omega \cdot \mathrm{cm}$ obtained in our study is also the lowest value reported thus far for the $\mathrm{Cu}_{2} \mathrm{O}$ films deposited by PLD [24-26]. Good electrical properties of low resistivity, high Hall mobility and proper carrier concentration are essential for fabricating high performance $\mathrm{Cu}_{2} \mathrm{O}$-based functional devices like solar cells and thin film transistors. As the $\mathrm{P}_{\mathrm{O}_{2}}$ increases further to $0.12 \mathrm{~Pa}$, the carrier concentration decreases due to the formation of $\mathrm{CuO}$ phase and therefore the decrease of $\mathrm{Cu}$ vacancies. In the meantime, the obvious degradation of 
film crystallinity leads to the decline of Hall mobility. Consequently, an increase of electrical resistivity is observed for the $0.12 \mathrm{~Pa}$-deposited film.

\section{Conclusions}

Copper oxide thin films were deposited on $\mathrm{MgO}$ (110) substrates by the PLD technique and the influence of oxygen pressure on the film properties was systematically investigated. The structure, crystallinity and morphology of the films were strongly affected by the oxygen pressure. The variation of oxygen pressure in our study could not only change the thermodynamic conditions but also alter the plasma dynamics and therefore the film growth mode, which in turn could result in the formation of different $\mathrm{Cu}-\mathrm{O}$ phases and film surface morphologies. The 0.09-Pa-deposited film was pure single-crystalline $\mathrm{Cu}_{2} \mathrm{O}$ with an epitaxial relationship of $\mathrm{Cu}_{2} \mathrm{O}(110) / / \mathrm{MgO}$ (110) with $\mathrm{Cu}_{2} \mathrm{O}(001) / / \mathrm{MgO}$ (001). An obvious influence of oxygen pressure on the transmittance of the films was also observed and a variation of the optical band gap from 2.33 to $2.57 \mathrm{eV}$ was obtained. The lowest resistivity of 6.67 $\Omega \cdot \mathrm{cm}$ with the highest carrier concentration of $3.94 \times 10^{16} \mathrm{~cm}^{-3}$ and highest Hall mobility of $23.75 \mathrm{~cm}^{2} \cdot \mathrm{v}^{-1} \cdot \mathrm{s}^{-1}$ were obtained for the film deposited under the oxygen pressure of 0.09 $\mathrm{Pa}$. High quality $\mathrm{Cu}_{2} \mathrm{O}$ single-crystalline films with good electrical properties may pave the way for realizing high performance $\mathrm{Cu}_{2} \mathrm{O}$-based functional devices such as thin film transistors and solar cells.

\section{Acknowledgements}

This work was supported by the National Natural Science Foundation of China 
(Grant No. 51602180), Key Research and Development Program of Shandong Province, China (Grant Nos. 2016GGX104013 and 2017GGX201007), and China Postdoctoral Science Foundation (Grant No. 2016M602140).

\section{References}

[1] D.P. Norton, Synthesis and properties of epitaxial electronic oxide thin-film materials, Mater. Sci. Eng., R, 43 (2004) 139-247.

[2] L. Liao, B. Yan, Y.F. Hao, G.Z. Xing, J.P. Liu, B.C. Zhao, Z.X. Shen, T. Wu, L. Wang, J.T.L. Thong,

C.M. Li, W. Huang, T. Yu, P-type electrical, photoconductive, and anomalous ferromagnetic properties of $\mathrm{Cu}_{2} \mathrm{O}$ nanowires, Appl. Phys. Lett., 94 (2009) 113106.

[3] T. Mahalingam, J.S.P. Chitra, S. Rajendran, M. Jayachandran, M.J. Chockalingam, Galvanostatic deposition and characterization of cuprous oxide thin films, J. Cryst. Growth, 216 (2000) 304-310.

[4] S.C. Ray, Preparation of copper oxide thin film by the sol-gel-like dip technique and study of their structural and optical properties, Sol. Energy Mater. Sol. Cells, 68 (2001) 307-312.

[5] A.A. Ogwu, E. Bouquerel, O. Ademosu, S. Moh, E. Crossan, F. Placido, The influence of rf power and oxygen flow rate during deposition on the optical transmittance of copper oxide thin films prepared by reactive magnetron sputtering, J. Phys. D: Appl. Phys., 38 (2005) 266-271.

[6] J.F. Pierson, A. Thobor-Keck, A. Billard, Cuprite, paramelaconite and tenorite films deposited by reactive magnetron sputtering, Appl. Surf. Sci., 210 (2003) 359-367.

[7] B. Balamurugan, B.R. Mehta, Optical and structural properties of nanocrystalline copper oxide thin films prepared by activated reactive evaporation, Thin Solid Films, 396 (2001) 90-96. 
[8] E. Fortin, F.L. Weichman, Hall effect and electrical conductivity of $\mathrm{Cu}_{2} \mathrm{O}$ monocrystals, Can. J. Phys., 44 (1966) 1551-1561.

[9] H. Jing, Z. Yu, L. Li, Antibacterial properties and corrosion resistance of $\mathrm{Cu}$ and $\mathrm{Ag} / \mathrm{Cu}$ porous materials, J. Biomed. Mater. Res., Part A, 87A (2008) 33-37.

[10] T. Minami, Y. Nishi, T. Miyata, J.-i. Nomoto, High-Efficiency Oxide Solar Cells with $\mathrm{ZnO} / \mathrm{Cu}_{2} \mathrm{O}$ Heterojunction Fabricated on Thermally Oxidized Cu2O Sheets, Appl. Phys. Express, 4 (2011) 062301.

[11] Y. Nishi, T. Miyata, J.-i. Nomoto, T. Minami, Influence of $\mathrm{Cu}_{2} \mathrm{O}$ surface treatment on the photovoltaic properties of Al-doped $\mathrm{ZnO} / \mathrm{Cu}_{2} \mathrm{O}$ solar cells, Thin Solid Films, 520 (2012) 3819-3822.

[12] T. Minami, Y. Nishi, T. Miyata, Heterojunction solar cell with $6 \%$ efficiency based on an n-type aluminum-gallium-xide thin film and p-type sodium-doped $\mathrm{Cu}_{2} \mathrm{O}$ sheet, Appl. Phys. Express, 8 (2015) 022301.

[13] X. Zou, G. Fang, L. Yuan, M. Li, W. Guan, X. Zhao, Top-gate low-threshold voltage p-Cu $\mathrm{Cu}_{2}$ thin-film transistor grown on $\mathrm{SiO}_{2} / \mathrm{Si}$ substrate using a high-kappa HfON gate dielectric, IEEE Electron Device Lett, 31 (2010) 827-829.

[14] W. Maeng, S.-H. Lee, J.-D. Kwon, J. Park, J.-S. Park, Atomic layer deposited p-type copper oxide thin films and the associated thin film transistor properties, Ceram. Int., 42 (2016) 5517-5522.

[15] L.C. Olsen, F.W. Addis, W. Miller, Experimental and theoretical-studies of $\mathrm{Cu}_{2} \mathrm{O}$ solar-cell, Sol. Cells, 7 (1982) 247-279.

[16] Y. Fu, H. Lei, X. Wang, D. Yan, L. Cao, G. Yao, C. Shen, L. Peng, Y. Zhao, Y. Wang, W. Wu, Fabrication of two domain $\mathrm{Cu}_{2} \mathrm{O}(011)$ films on $\mathrm{MgO}(001)$ by pulsed laser deposition, Appl. Surf. Sci., 273 (2013) 19-23.

[17] L.S. Huang, S.G. Yang, T. Li, B.X. Gu, Y.W. Du, Y.N. Lu, S.Z. Shi, Preparation of large-scale 
cupric oxide nanowires by thermal evaporation method, J. Cryst. Growth, 260 (2004) 130-135.

[18] Z.Q. Yu, C.M. Wang, M.H. Engelhard, P. Nachimuthu, D.E. McCready, I.V. Lyubinetsky, S. Thevuthasan, Epitaxial growth and microstructure of $\mathrm{Cu}_{2} \mathrm{O}$ nanoparticle/thin films on $\mathrm{SrTiO}_{3}(100)$, Nanotechnology, 18 (2007) 115601.

[19] F. Oba, F. Ernst, Y.S. Yu, R. Liu, M. Kothari, J.A. Switzer, Epitaxial growth of cuprous oxide electrodeposited onto semiconductor and metal substrates, J. Am. Ceram. Soc., 88 (2005) 253-270.

[20] B. Shin, J.P. Leonard, J.W. McCamy, M.J. Aziz, Comparison of morphology evolution of Ge(001) homoepitaxial films grown by pulsed laser deposition and molecular-beam epitaxy, Appl. Phys. Lett., 87 (2005) 181916.

[21] G. Li, W. Wang, W. Yang, H. Wang, Epitaxial growth of group III-nitride films by pulsed laser deposition and their use in the development of LED devices, Surf. Sci. Rep., 70 (2015) 380-423.

[22] S.R.C. McMitchell, Research Update: New possibilities for the nanoscale engineering of complex oxide thin films, APL Mater., 3 (2015) 062301.

[23] G. Kaur, A. Mitra, K.L. Yadav, Influence of oxygen pressure on the growth and physical properties of pulsed laser deposited $\mathrm{Cu}_{2} \mathrm{O}$ thin films, J. Mater. Sci.: Mater. Electron., 26 (2015) 9689-9699.

[24] K. Matsuzaki, K. Nomura, H. Yanagi, T. Kamiya, M. Hirano, H. Hosono, Epitaxial growth of high mobility $\mathrm{Cu}_{2} \mathrm{O}$ thin films and application to p-channel thin film transistor, Appl. Phys. Lett., 93 (2008) 202107.

[25] K. Matsuzaki, K. Nomura, H. Yanagi, T. Kamiya, M. Hirano, H. Hosono, Effects of post-annealing on (110) $\mathrm{Cu}_{2} \mathrm{O}$ epitaxial films and origin of low mobility in $\mathrm{Cu}_{2} \mathrm{O}$ thin-film transistor, Phys. Status Solidi A, 206 (2009) 2192-2197.

[26] F.-Y. Ran, H. Hiramatsu, H. Hosono, T. Kamiya, M. Taniguti, Detection of dead layers and defects 
in polycrystalline $\mathrm{Cu}_{2} \mathrm{O}$ thin-film transistors by $\mathrm{x}$-ray reflectivity and photoresponse spectroscopy analyses, J. Vac. Sci. Technol., B, 33 (2015) 051211.

[27] S.K. Pang, A.W. Smith, A. Rohatgi, Effect of trap location and trap-assisted auger recombination on silicon solar-cell preformance, IEEE Trans. Electron Devices, 42 (1995) 662-668.

[28] J.A. Caraveo-Frescas, P.K. Nayak, H.A. Al-Jawhari, D.B. Granato, U. Schwingenschloegl, H.N. Alshareeft, Record mobility in transparent p-type tin monoxide films and devices by phase engineering, Acs Nano, 7 (2013) 5160-5167.

[29] H.Y.Y. B. Yaglioglu, R. Beresford, and D. C. Paine, High-mobility amorphous $\operatorname{In}_{2} \mathrm{O}_{3}-10 \mathrm{wt} \% \mathrm{ZnO}$ thin film transistors Appl. Phys. Lett., 89 (2006) 062103.

[30] A. Soon, M. Todorova, B. Delley, C. Stampfl, Thermodynamic stability and structure of copper oxide surfaces: A first-principles investigation, Phys. Rev. B, 75 (2007) 125420.

[31] W.S. Brower, H.S. Parker, Growth of single crystal cuprous oxide, J. Cryst. Growth, 8 (1971) $227-229$.

[32] A. Subramaniyan, J.D. Perkins, R.P. O'Hayre, S. Lany, V. Stevanovic, D.S. Ginley, A. Zakutayev, Non-equilibrium deposition of phase pure $\mathrm{Cu}_{2} \mathrm{O}$ thin films at reduced growth temperature, APL Mater., $2(2014) 022105$.

[33] A. Sahai, N. Goswami, S.D. Kaushik, S. Tripathi, $\mathrm{Cu} / \mathrm{Cu}_{2} \mathrm{O} / \mathrm{CuO}$ nanoparticles: Novel synthesis by exploding wire technique and extensive characterization, Appl. Surf. Sci., 390 (2016) 974-983.

[34] A.E. Nelsona, K.H. Schulzb, Surface chemistry and microstructural analysis of $\mathrm{Ce}_{x} \mathrm{Zr}_{1-x} \mathrm{O}_{2-y}$ model catalyst surfaces, Appl. Surf. Sci. 210 (2003) 206-221.

[35] A.H. Jayatissa, K. Guo, A.C. Jayasuriya, Fabrication of cuprous and cupric oxide thin films by heat treatment, Appl. Surf. Sci., 255 (2009) 9474-9479. 
[36] A.A. Ogwu, E. Bouquerel, O. Ademosu, S. Moh, E. Crossan, F. Placido, An investigation of the surface energy and optical transmittance of copper oxide thin films prepared by reactive magnetron sputtering, Acta Mater., 53 (2005) 5151-5159.

[37] M.R. Johan, M.S.M. Suan, N.L. Hawari, H.A. Ching, Annealing Effects on the Properties of Copper Oxide Thin Films Prepared by Chemical Deposition, International Journal of Electrochemical Science, 6 (2011) 6094-6104.

[38] M.H.P. Reddy, J.F. Pierson, S. Uthanna, Structural, surface morphological, and optical properties of nanocrystalline $\mathrm{Cu}_{2} \mathrm{O}$ and $\mathrm{CuO}$ films formed by $\mathrm{RF}$ magnetron sputtering: Oxygen partial pressure effect, Phys. Status Solidi A, 209 (2012) 1279-1286. 
Figure Captions:

Fig. 1. (a) XRD patterns of copper oxide films grown on $\mathrm{MgO}$ (110) substrates under typical oxygen pressures. Plan view SEM micrographs of the copper oxide films grown under the oxygen pressures of (b) 0.02, (c) 0.06, (d) 0.09 and (e) $0.12 \mathrm{~Pa}$.

Fig. 2. In-plane XRD patterns of (a) and (b) $\Phi$-scan as well as (c) $2 \theta \chi$-scan for the sample grown under $\mathrm{P}_{\mathrm{O}_{2}}$ of $0.09 \mathrm{~Pa}$.

Fig. 3. (a) Low magnification TEM and (b) HRTEM images of the film-substrate interface and (c) SAED micrographs of the film portion for the 0.09 Pa-deposited sample.

Fig. 4. XPS spectra of the $\mathrm{Cu}_{2} \mathrm{O}$ film grown under $\mathrm{P}_{\mathrm{O}_{2}}$ of $0.09 \mathrm{~Pa}$ : (a) survey, (b) $\mathrm{Cu}$ 2p core levels, (c) Cu LMM Auger spectrum and (d) O 1s core level.

Fig. 5. Transmittance spectra of the copper oxide films prepared under typical oxygen pressures with the plots of $(\alpha h v)^{2}$ versus $h v$ shown in the inset.

Fig. 6. Hall mobility, carrier concentration and resistivity of the copper oxide films as a function of the oxygen pressure. 